\title{
Comparison of Laparoscopic Embedding Technique and Other Techniques for Appendiceal Stump Closure
} Apendiks Güdüğünün Kapatılmasında Laparoskopik Gömme Tekniğinin
Diğer Tekniklerle Karşılaştırması

\author{
(1) Mehmet Emin Güneş, (1) Eyüp Gemici, () Turgut Dönmez \\ İstanbul Bakırköy Dr. Sadi Konuk Training and Research Hospital, Clinic of General Surgery, İstanbul, Turkey
}

\section{|IIIIIII| ABSTRACT}

Aim: Acute appendicitis is the most common surgical emergency worldwide. Laparoscopic appendectomyis widely used in acute appendicitis. In our study, we aimed to investigate the efficacy and safety of laparoscopic embedding technique.

Method: Patients who underwent laparoscopic embedding technique for appendiceal stump between July 2017 and December 2018 were included in the study. Acute appendicitis was diagnosed by physical examination, laboratory tests, ultrasound and computed tomography scan. Dissection of the mesoappendix was performed with a bipolar tissue sealing system, and then the appendix radix was ligated using intracorporeal knotting technique and inverted into the cecum with a suture. The patients were evaluated in terms of age, gender, body mass index (BMI), rate of conversion, operative time, postoperative complications and length of hospital stay.

Results: The mean age was $34.81 \pm 1.88$ years and the mean BMI was $27.51 \pm 5.44 \mathrm{~kg} / \mathrm{m}^{2}$. The mean operative time was $61.93 \pm 17.67 \mathrm{minutes}$. Thirtytwo patients had complicated appendicitis and 39 patients had uncomplicated appendicitis. In patients with uncomplicated appendicitis, four patients developed surgical site infection and two patients had ileus; whereas two patients developed ileus and three patients developed surgical site infection in complicated appendicitis cases. The mean length of hospital stay was $38.92 \pm 25.90$ hours.

Conclusion: Laparoscopic embedding technique is easy, simple, safe, fast and effective for acute appendicitis and will become the method of choice in securing the base of the appendix in complicated appendicitis.

Keywords: Laparoscopic appendectomy, acute appendicitis, appendiceal stump

\section{|IIIIIII| ÖZ}

Amaç: Akut apandisit tüm dünyada en sık görülen cerrahi acil durumdur. Laparoskopik apendektomi akut apandisit ameliyatlarında yaygın olarak kullanılmaktadır. Apendiks güdüğünün kapatılmasında birçok teknik kullanılmıștır. Çalışmamızda, laparoskopik gömme tekniğinin etkinlik ve güvenilirliğini araştırmayı amaçladık.

Yöntem: Temmuz 2017-Aralık 2018 tarihleri arasında akut apandisit için apendiks güdügünün kapatılmasında laparoskopik gömme yöntemi kullanılan hastalar dahil edildi. Fizik muayene, laboratuvar testleri, ultrason ve bilgisayarlı tomografi muayenesi ile akut apandisit tanısı kondu. Mezoapendiksin diseksiyonu bir LigaSure cihazı ile yapıldı ve daha sonra apendiks radiks intrakorporeal düğumleme tekniği ile bağlandı ve bir keseli dikiş ipliği ile çekuma ters çevrildi. Hastalar yaş, cinsiyet, vücut kitle indeksi (VKİ), dönüşüm oranı, ameliyat süresi, ameliyat sonrası komplikasyonlar ve hastanede kalış süresi açısından incelendi.

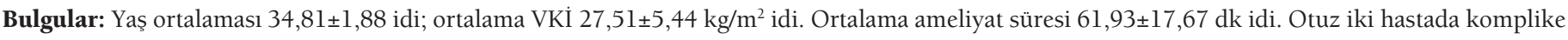
apandisit, 39 hastada komplike olmayan apandisit vard. Komplike olmayan apandisitli hastalarda, 4 hastada cerrahi alan enfeksiyonu ve 2 hastada ileus gelişti; komplike apandisit olgularında 2 hastada ileus, 3 hastada cerrahi alan enfeksiyonu gelişti. Ortalama hastanede kalış süresi 38,92 25,90 saat idi.

Sonuç: Laparoskopik gömme tekniği akut apandisit için kolay, basit, güvenli, hızlı ve etkilidir ve komplike apandisitte appendiks tabanının güvenliğinde tercih edilen yöntem olacaktır.

Anahtar Kelimeler: Laparoskopik apendektomi, akut apandisit, apendiks güdüğü

Address for Correspondence/Yazışma Adresi: Turgut Dönmez MD,

İstanbul Bakırköy Dr. Sadi Konuk Training and Research Hospital, Clinic of General Surgery, İstanbul, Turkey

Phone: +90 5347400967 E-mail: surgeont73@hotmail.com ORCID ID: orcid.org/0000-0003-3095-2195

Received/Gelis Tarihi: 26.01.2019 Accepted/Kabul Tarihi: 25.02.2019

${ }^{\circ}$ Copyright 2019 by Turkish Society of Colon and Rectal Surgery

Turkish Journal of Colorectal Disease published by Galenos Publishing House. 


\section{Introduction}

Appendicitis is a common condition affecting the population of all ages; however, it usually affects young and healthy people. Appendicitis accounts for approximately 25\% of patients admitted to emergency surgery clinics and $>40 \%$ of all emergency laparotomies. ${ }^{1,2}$ Laparoscopic appendectomy (LA) was first described by Semm. ${ }^{3}$ Compared to open appendectomy (OA), LA caused less pain, faster return to normal activities, better cosmetic outcomes and shorter hospital stay. ${ }^{4,5}$ The most common concern regarding LA is the closure of the appendiceal stumps. The most important reason is that it can affect the outcome in terms of infectious complications. However, evidence and studies in the literature reveal conflicting results. ${ }^{6,7}$ Therefore, the optimal closure type of the appendiceal stumps is still under discussion. Endoloop, endostapler, metal endoclip, Hem-OLok clip and intracorporeal ligation were used to close the appendiceal stumps. . $^{2,7,8,9,10,11}$ Complicated appendicitis (CA) means a gangrenous and/or perforated appendix that can lead to abscess formation and peritonitis. The laparoscopic grading system (LGS) of acute appendicitis (AA) was first described by Gomes et al. ${ }^{12}$ It should be kept in mind that appendix base necrosis, which is the most common reason for procedure failure in some patients, is the most important factor in the closure of the appendix in most studies. ${ }^{9,10,11}$ The most common complications after LA are of infectious origin, especially postoperative intraabdominal abscess (POIAA) formation. It has been emphasized that appendiceal stump leakage may be an important factor in POIAA formation. ${ }^{13}$ In this study, we aimed to investigate the efficacy and safety laparoscopic intracorporeal knotting (ICK) and purse string suture (PSS) in AA.

\section{Materials and Methods}

This retrospective study was conducted by two surgeons experienced in laparoscopic surgery in a 100-bed training and research hospital in İstanbul between February 2017 and October 2018. We retrospectively examined 71 patients with AA who underwent LA. AA was diagnosed by abdominal ultrasound (45 patients) or computed tomography (26 patients). The diameter of the appendix was measured by ultrasound or computed tomography. The LA techniques selected were the surgeon's own preference. Seventy-one patients who underwent laparoscopic ICK and PSS were included in the study. Patients with sepsis and shock were not included. Informed consent was obtained from all patients before surgery. LGS of AA was used to grade the disease (Table 1). ${ }^{12}$ Age, gender, height, weight, body mass index (BMI) and comorbid diseases of the patients were recorded. Operative time, complications, appendix diameter, drainage,
C-reactive protein, white blood cell count, length of hospital stay, and time of enteral feeding were recorded. Postoperative complications such as trocar site infection, bleeding, stump leakage, ileus and POIAA were recorded. This study was approved by Bakırköy Dr. Sadi Konuk Training and Research Hospital Ethics Committee (approval no: 2018-22, Date: 03.12.2018). The surgeries were performed by a lefthanded surgeon and an assistant (laparoscopy technician). All patients were given general anesthesia. After general anesthesia induction, a temporary Foley catheter and an orogastric tube were inserted to prevent visceral injury, and they were removed before the patient recovered from anesthesia. A $1 \mathrm{~cm}$ skin incision was performed under the umbilicus and the abdominal cavity was accessed with a Veress needle. A $14 \mathrm{mmHg} \mathrm{CO}_{2}$ pressure was generated for pneumoperitoneum and a $10 \mathrm{~mm}$ trocar was inserted in the intraperitoneal cavity. After inserting a $30^{\circ}, 10 \mathrm{~mm}$ optical camera through the umbilical trocar, a $10 \mathrm{~mm}$ trocar and a $5 \mathrm{~mm}$ trocar were placed under direct vision in the left lower quadrant and suprapubic region, respectively. The patients were positioned at an angle of 15 degrees in the Trendelenburg position on the left. Diagnostic investigation was performed and AA was confirmed (Figure 1). Dissection

Table 1. Laparoscopic grading system of acute appendicitis according to macroscopic inflammatory findings

$\begin{array}{ll}\text { Grade } & \text { Laparoscopic findings } \\ \text { Grade } 0 & \text { Normal looking appendix } \\ \text { Grade } 1 & \text { Hyperemia and edema } \\ \text { Grade 2 } & \text { Fibrinous exudate } \\ \text { Grade 3A } & \text { Segmental necrosis } \\ \text { Grade 4A } & \text { Abscess } \\ \text { Grade 4B } & \text { Regional peritonitis } \\ \text { Grade 5 } & \text { Diffuse peritonitis }\end{array}$

From Gomes et al. ${ }^{12}$

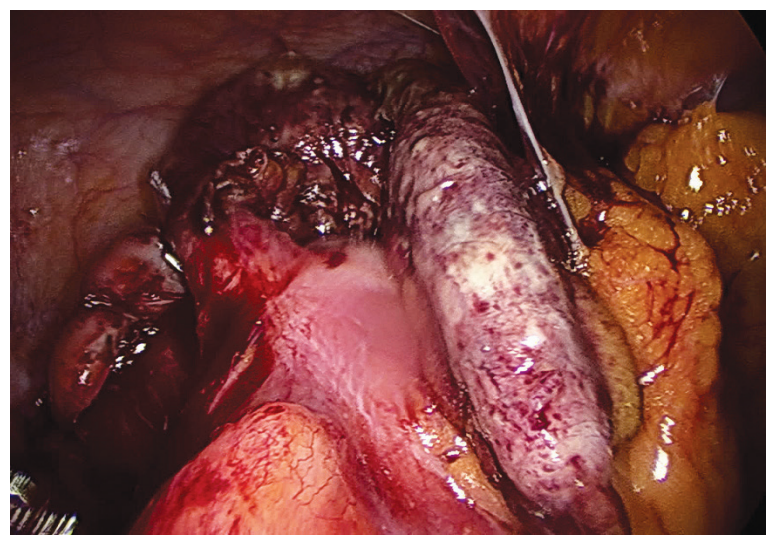

Figure 1. View of complicated acute appendicitis 
of the mesoappendix was performed with a $5 \mathrm{~mm}$ or $10 \mathrm{~mm}$ bipolar tissue sealing system (LigaSure ${ }^{\circledast}$ Valleylab, Boulder, $\mathrm{CO}$ ) as close as possible to minimize at least a portion of the dissection. The appendix base is exposed to the appendix base with $2 / 0$ vicryl and is secured by ICK (Figure 2). The standard node type used was a square knot with two turns in the first shot and one turn in the last two. Following appendectomy, a sample was removed from the sample bag in the left lower quadrant. If there was no localized haze accumulation in the pelvic region, irrigation was preferred according to irrigation only. Atraumatic 3/0 silk with PSS was passed. The appendix stump was embedded in the cecum of

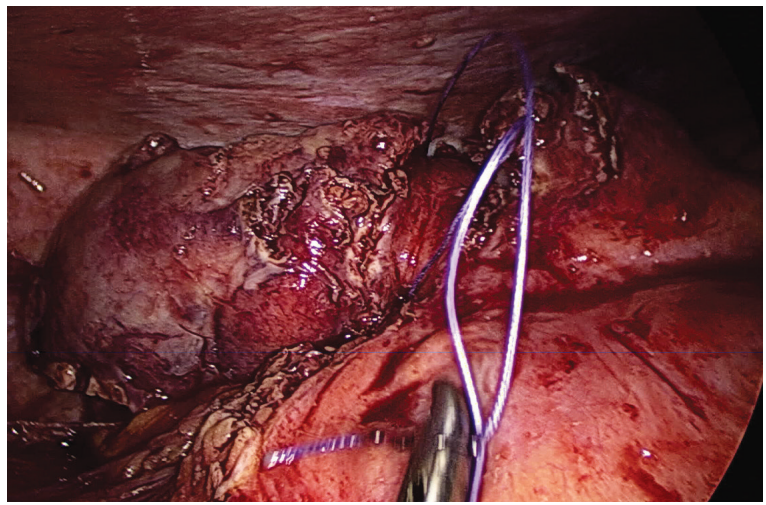

Figure 2. Appendiceal stump closure by intracorporeal knotting technique in grade 3 a complicated acute appendicitis

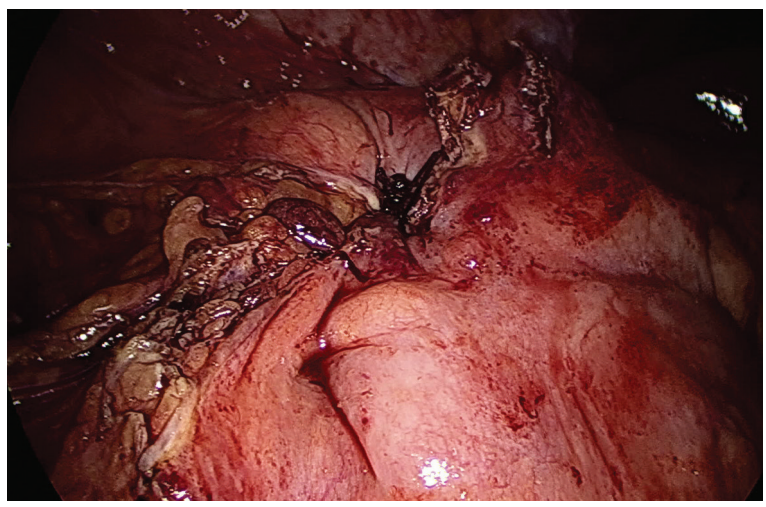

Figure 3a. Atraumatic 3-0 silk suture from the base of the cecum

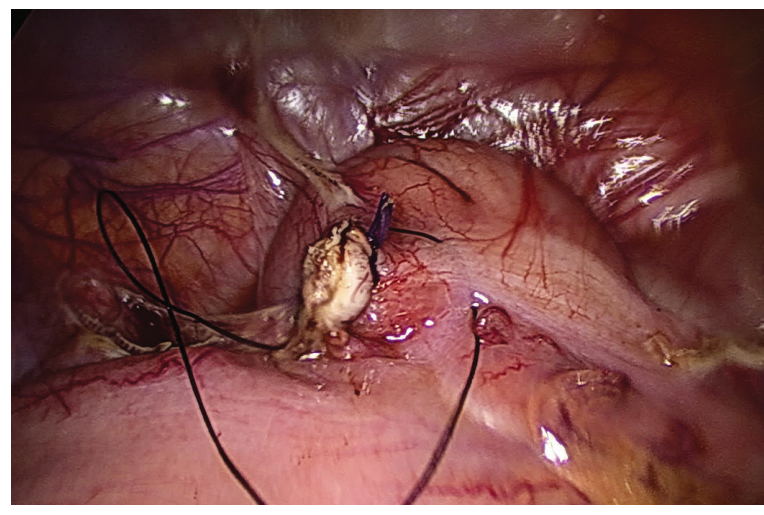

Figure $3 \mathbf{b}$. The appendix stump was embedded in the cecum the knot (Figure 3a, b). After the control of bleeding in cases of non-appendicitis, the operation was stopped. The fascia was closed with $2 / 0$ vicryl and the skin was closed with $4 / 0$ intracutaneous vicryl suture. All patients, except those who had nausea or vomiting, began to take oral intake at the $4^{\text {th }}$ hour postoperatively. Diclofenac sodium $(75 \mathrm{mg}$ twice daily, intramuscular) was administered for the treatment of postoperative pain and was replaced with naproxen sodium (550 mg twice daily, per oral) after oral administration. The patients were followed up 30 days after the operation. All findings of the applications for dressing changes and sutures and postoperative complications were recorded.

\section{Statistical Analysis}

Statistical analysis was performed using SPSS version 17.0 (SPSS Inc., Chicago, IL, USA). Quantitative variables were expressed as mean \pm standard deviation or range, whereas categorical variables, such as number of patients, were expressed as a percentage.

\section{Results}

The appendiceal stump closure by ICK and PSS was viable in 71 (100\%) patients who underwent LA for AA. Seventy one (25 female, 46 male) patients were included. The mean age was $34.81 \pm 12.88$ years and the mean BMI was $27.51 \pm 5.44$ $\mathrm{kg} / \mathrm{m}^{2}$. Forty four patients were American Society of Anesthesiologists (ASA) 1, 21 patients were ASA 2, and 6 patients were ASA 3 (Table 2).

The mean operative time was $67.64 \pm 16.26$ minutes (Table 2 ). The mean length of hospital stay was $38.92 \pm 25.9$ hours. The hospital stay was longer in cases of CA $(50.56 \pm 30.64$ hours) (Table 3).

Table 2. Patient demographic data

\begin{tabular}{ll} 
Variable & Patients $(\mathrm{n}=71)$ \\
\hline Age, year & $34.81 \pm 12.88$ \\
Gender (female/male), n & $25 / 46$ \\
BMI, $\mathrm{kg} / \mathrm{m}^{2}$ & $27.51 \pm 5.44$ \\
ASA $1 / 2 / 3, \mathrm{n}$ & $44 / 21 / 6$ \\
WBC, $10^{3} / \mathrm{mm}^{3}$ & $14.618 \pm 3833$ \\
CRP & $7.36 \pm 5.83$ \\
Appendix diameter, mm & $10.24 \pm 2.4$ \\
Uncomplicated appendectomy, n (\%) & $39(54.92)$ \\
Complicated appendectomy, $\mathrm{n}(\%)$ & $32(45.08)$
\end{tabular}

Values are presented as mean \pm standard deviation, n: number of patients

BMI: Body mass index, ASA: American Association of Anesthesiology score, WBC: White blood cell count, CRP: C-reactif protein 
According to laparoscopic grading in acute $\mathrm{CA}$, nine patients were grade $3 \mathrm{~A}$, eight patients were grade $3 \mathrm{~B}$, six patients were grade $4 \mathrm{~A}$, five patients were grade $4 \mathrm{~B}$ and four patients were grade 5 . The mean time spent in LA for complicated degrees of AA was $74.93 \pm 15.16$ minutes. Drainage was placed in three cases with uncomplicated appendicitis (UCA) and four cases with CA due to minimal hemorrhage in Douglas pouch. After surgery, four patients developed ileus and recovered with surgical treatment. Surgical site infections were wound infection in five patients (7.04\%) and POIAA (1.4\%) in one patient (5.08\%). A $5 \mathrm{~cm}$ abscess was detected in the Douglas in one patient. The abscess was evacuated with an ultrasound-guided catheter. All other patients recovered completely (Table 3).

\section{Discussion}

AA is one of the most common causes of acute abdominal pain, with an annual incidence of 250.000 patients in the United States and 50.000 patients requiring emergency surgical intervention in the United Kingdom. ${ }^{14}$ AA is a common surgical emergency with an incidence of 1.17 per 1000 patients, with a lifetime incidence of $8.6 \%$ in women (6.7\%) and also in men (6.7\%). LA has the advantage of reducing the need for analgesics, shorter hospital stay, early return to work, better cosmetic results and lower wound infection rate. ${ }^{4,5}$ The laparoscopic technique also provides a clear view of the entire abdominal cavity in case of acute abdomen. Although LA has become a common method for the treatment of AA in recent years, its role in patients with CA remains controversial. Some reports have suggested that LA may be associated with higher rates of intraabdominal infection in the treatment of CA. ${ }^{15,16}$ Improper closure of the appendix stump is an important step during appendectomy as it may cause serious postoperative complications. Endostapler, ${ }^{7,10,17,18}$ endo ligature (endoloop), ${ }^{7,8,18}$ metal endoclips, ${ }^{2,11,19,20,21}$ bipolar endocoagulation, polymeric endoclips (hem-o-log clip) $)^{9,10,22}$ and intracorporeal suture ${ }^{2,3,23}$ are used for the closure of the appendix stump in LA. ${ }^{24}$ Complications of appendicitis are very important in patients with CA. The classification of appendicitis is also very important. To facilitate this, Gomes et al. ${ }^{12}$ classified macroscopic, laparoscopic technical difficulties according to peroperative macroscopic appearance (Table 1). In this classification, grade $3 \mathrm{~b}$ is particularly important. However, there are very few reports about stump leakage in the literature. ${ }^{13}$ In a clinical prospective randomized study by Tagguchi et al. ${ }^{13}$ four appendiceal stump leakages were detected with endostapler in CA cases. Gomes et al. ${ }^{12}$ used a CA metal clip application to close the stump. In the study, a metal clip was successfully applied in 118 of 131 cases. In this study, it was impossible to apply metal clips in 12 grade $3 \mathrm{~b}$ (appendix base necrosis) cases. In these cases, the appendix stump was connected to the laparoscopic suture or laparotomy with open technique. ${ }^{12}$ In other studies, we do not know the reason, whether it was because of the lack of stump leakage or other reasons. In our study, eight cases among 32 patients with CA were diagnosed laparoscopically as grade $3 \mathrm{~b}$. They were treated with PSS. No re-operation was required in any case. The mean operative time in UCA cases was $61.93 \pm 17.67$ minutes, the lowest compared with the other four studies,,$^{24,25,26}$ but similar to those reported by Ates et al. ${ }^{2}$ and Gonenc et al. ${ }^{23}$ (Table 4). The mean working time for complicated degrees of AA during LA was compared with four other similar studies $(n=32)$ (Table 5$)$. The mean operative time in CA cases was $74.93 \pm 15.16$ minutes. The operative time was lower in the studies by Ay et al. ${ }^{27}$ and Gomes et al. ${ }^{11}$ compared to previous studies (Table 5).

Table 3. Surgery data

\begin{tabular}{|c|c|c|c|}
\hline Variable & Uncomplicated appendectomy & Complicated appendectomy & Total \\
\hline Operative time, minute & $61.93 \pm 17.67$ & $74.93 \pm 15.16$ & $67.64 \pm 16.26$ \\
\hline Hospital stay, hours & $29.38 \pm 16.18$ & $50.56 \pm 30.64$ & $38.92 \pm 25.9$ \\
\hline Oral diet, day & $1.26(1-2)$ & $1.43(1-3)$ & $1.34(1-3)$ \\
\hline Drainage $(+)$ & $3(7.69 \%)$ & $32(100 \%)$ & $35(49.29 \%)$ \\
\hline Complication & $4(10.25 \%)$ & $6(18.75 \%)$ & $10(14.08 \%)$ \\
\hline Ileus & $2(5.125 \%)$ & $2(6.25 \%)$ & $4(5.63 \%)$ \\
\hline Trocar site infection & $2(5.125 \%)$ & $3(9.375 \%)$ & $5(7.04 \%)$ \\
\hline Intraabdominal abscess & 0 & $1(3.125 \%)$ & $1(1.4 \%)$ \\
\hline Appendix stump leakage, $\mathrm{n}$ & 0 & 0 & 0 \\
\hline Bleeding, $n$ & 3 & 4 & 7 \\
\hline
\end{tabular}

Values are presented as mean \pm standard deviation or median (range), n: number of patients 
The surgical technique used in the study by Ay et al. ${ }^{27}$ was similar to our technique and they closed the appendiceal stump with ICK. In our technique, in addition to stump security, the appendix is buried into the stump cecum and embedded by using PSS. This explains our longer working hours. In the study of Ay et al. ${ }^{27}$ no adequate data were presented for CA grade $3 \mathrm{~b}$ cases. They emphasized that they failed using metal clips method by Gomes et al. ${ }^{12}$ in grade $3 \mathrm{~b}$ cases to close the stump and that they preferred laparotomy or additional methods in these cases. In a randomized clinical study conducted by Taguchi et al. ${ }^{13}$ four cases of stump leakage were found in the closed appendiceal stump with the technique of bipolar endocoagulation in CA cases. The operative time in the studies by Taguchi et al. ${ }^{13}$ and Quezada et al. ${ }^{28}$ was longer than in our study. In our study, patients with an abscess had a longer operative time, which may explain the presence of appendiceal inflammatory processes, aspiration of abscess formation, irrigation, and a more difficult operation. LA has been proven to be a safe procedure in the management of UCA.,12 However, there are controversial data about the indications of laparoscopy in relation to the rate of POIAA in CA. ${ }^{12,13,14,15,16,17}$ It may be reasonable to assume that the presence and proliferation of peritonitis may be a risk factor for POIAA, and therefore, necrotic perforated appendicitis in the intraabdominal space may have a lower risk of POIAA than cases complicated by peritonitis. ${ }^{3,12,14,16,17,28}$ Another issue discussed is that abundant irrigation of the abdominal cavity with $0.9 \%$ saline solution is shown as one of the causes of abscess development. ${ }^{3}$ In a clinical study performed by Katkhouda et al. ${ }^{17}$ the examination of the Douglas, irrigation, aspiration and the use of endobags removed abscesses and necrotic fragments from cavities and reduced the frequency of POIAA from $2.4 \%$ to $0.4 \%$. The frequency of intraabdominal infection and percutaneous drainage under abdominal ultrasound in our study was similar (3.1\%) (Table 3). None of the patients required reoperation and all had a smooth recovery. In this context, the treatment of the appendix stump using laparoscopic ligation and PSS technique is considered as a safe and effective alternative.

In some cases, it may be necessary to switch from LA to OA. The need for laparotomy may be $0 \%$ to $39.7 \%$., ${ }^{4,56,17,18,26,28}$ Laparotomy causes adhesions, local perforation, diffuse peritonitis, appendix base necrosis, retrocecal position, bleeding, appendicular tumor and inability to identify iatrogenic lesions..$^{27,28,29,30}$ In our study, none of the 71 patients required laparotomy. Four patients with developed paralytic ileus responded to medical treatment. In CA and UCA cases with varying degrees, laparoscopic ligation and closure of the appendix stump with PSS is a safe and

Table 4. Mean operative time spent during laparoscopic appendectomy for uncomplicated acute appendicitis from four similar studies $(\mathrm{n}=39)$

\begin{tabular}{lcc}
\multicolumn{2}{l}{ Mean operative time in uncomplicated laparoscopic appendectomy } & $\mathrm{n}$ \\
\hline Study or subgroup & Mean \pm SD* & 30 \\
Ates et al. ${ }^{2}$ & $62.81 \pm 15.4$ & 46 \\
Gonenc et al. ${ }^{23}$ & $61.9 \pm 27.1$ & 40 \\
Kiudelis et al. ${ }^{25}$ & $79.6 \pm 21.1$ & 36 \\
Aziret et al. ${ }^{26}$ & $76.7 \pm 17.5$ & 39 \\
Our study & $61.93 \pm 17.67$ &
\end{tabular}

Table 5. Mean operative time spent during laparoscopic appendectomy for complicated acute appendicitis from four similar studies $(\mathrm{n}=32)$

\begin{tabular}{lll}
\multicolumn{2}{l}{ Mean operating time in complicated laparoscopic appendectomy } & \\
Study or subgroup & Mean \pm SD $^{*}$ & $\mathbf{n}$ \\
\hline Ay et al. ${ }^{27}$ & $54 \pm 48.85$ & 76 \\
Quezada et al. ${ }^{28}$ & $150 \pm 45$ & 42 \\
Taguchi et al. ${ }^{13}$ & $84.6 \pm 34.57$ & 131 \\
Gomes et al. ${ }^{11}$ & $67.4 \pm 28.1$ & 32
\end{tabular}

* Mean \pm standard deviation, n: sample number of each series 
effective procedure. In CA with appendix base necrosis, it is recommended to use other stump closure techniques.

\section{Ethics}

Ethics Committee Approval: Bakırköy Dr. Sadi Konuk Training and Research Hospital (approval no: 03.12.201822).

Informed Consent: Informed consent was obtained.

Peer-review: Internally peer-reviewed.

\section{Authorship Contributions}

Surgical and Medical Practices: T.D., E.G., Concept: M.E.G., T.D., E.G., Design: M.E.G., Data Collection or Processing: T.D., E.G., Analysis or Interpretation: M.E.G., Literature Search: E.G., Writing: T.D.

Conflict of Interest: No conflict of interest was declared by the authors.

Financial Disclosure: The authors declared that this study received no financial support.

\section{References}

1. Buckius MT, McGrath B, Monk J, Grim R, Bell T, Ahuja V. Changing epidemiology of acute appendicitis in the United States: study period 1993-2008. J Surg Res 2012;175:185-190.

2. Ates M, Dirican A, Ince V, Ara C, Isik B, Yilmaz S. Comparison of Intracorporeal Knot-tying Suture (Polyglactin) and Titanium Endoclips in Laparoscopic Appendiceal Stump Closure: A Prospective Randomized Study. Surg Laparosc Endosc Percutan Tech 2012;22:226-231.

3. Semm K. Endoscopic appendectomy. Endoscopy 1983;15:59-64.

4. Pedersen AG, Petersen OB, Wara P, Ronning H, Qvist N, Laurberg S. Randomized clinical trial of laparoscopic versus open appendicectomy. $\mathrm{Br}$ J Surg 2001;88:200-205.

5. Ukai T, Shikata S, Takeda S, Dawes L, Noguchi Y, Nakayama T, Tekemura YC. Evidence of surgical outcomes fluctuates over time: results from a cumulative meta-analysis of laparoscopic versus open appendectomy for acute appendicitis. BMC Gastroenterol 2016;16:37.

6. Kazemier G, in't Hof KH, Saad S, BonjerS HJ, Sauerland S. Securing the appendiceal stump in laparoscopic appendectomy: evidence for routine stapling? Surg Endosc 2006;20:1473-1476.

7. Sajid MS, Rimple J, Cheek E, Baig MK. Use of endo-GIA versus endo-loop for securing the appendicular stump in laparoscopic appendicectomy: a systematic review. Surg Laparosc Endosc Percutan Tech 2009;19:11-15.

8. Beldi G, Muggli K, Helbling C, Schlumpf R. Laparoscopic appendectomy using endoloops: a prospective, randomized clinical trial. Surg Endosc 2004;18:749-750.

9. Hanssen A, Plotnikov S, Dubois R. Laparoscopic appendectomy using a polymeric clip to close the appendiceal stump. JSLS 2007;11:59-62.

10. Al-Temimi MH, Berglin MA, Kim EG, Tessier DJ, Johna SD. Endostapler versus Hem-O-Lok clip to secure the appendiceal stump and mesoappendix during laparoscopic appendectomy. Am J Surg 2017;214:1143-1148.

11. Gomes CA, Junior CS, de Peixoto RO, Netto JM, Gomes CC, Gomes FC. Appendiceal stump closure by metal endoclip in the management of complicated acute appendicitis. World J Emerg Surg 2013;18;8:35.

12. Gomes CA, Nunes TA, Fonseca Chebli JM, Junior CS, Gomes CC. Laparoscopy grading system of acute appendicitis: new insight for future trials. Surg Laparosc Endosc Percutan Tech 2012;22:463-466.
13. Taguchi Y, Komatsu S, Sakamoto E, Norimizu S, Shingu Y, Hasegawa H. Laparoscopic versus open surgery for complicated appendicitis in adults: a randomized controlled trial. Surg Endosc 2016;30:1705-1712.

14. Findlay JM, Kafsi JE, Hammer C, Gilmour J, Gillies RS, Maynard ND. Nonoperative Management of Appendicitis in Adults: A Systematic Review and Meta-Analysis of Randomized Controlled Trials. J Am Coll Surg 2016;223:814-824.

15. Bat O, Kaya H, Çelik HK, Şahbaz NA. Clinical results of laparoscopic appendectomy in patients with complicated and uncomplicated appendicitis. Int J ClinExp Med 2014;7:3478-3481.

16. Krisher SL, Browne A, Dibbins A, Tkacz N, Curci M. Intra-abdominal abscess after laparoscopic appendectomy for perforated appendicitis. Arch Surg 2001;136:438-441.

17. Katkhouda N, Mason RJ, Towfigh S. Laparoscopic versus open appendectomy: a prospective, randomized, double blind study. Adv Surg 2006;40:1-19.

18. van Rossem CC, van Geloven AA, Schreinemacher MH, Bemelman WA; snapshot appendicitis collaborative study group. Endoloops or endostapler use in laparoscopic appendectomy for acute uncomplicated and complicated appendicitis: No difference in infectious complications. Surg Endosc 2017;31:178-184.

19. Cristalli BG, Izard V, Jacob D, Levardon M. Laparoscopic appendectomy using a clip applier. Surg Endosc 1991;5:176-178.

20. Gomes CA, Nunes TA: Classificaçãolaparoscópica da apendiciteaguda. Correlação entre graus da doença e as variáveis perioperatórias. Rev Col Bras Cir 2006;33:289-293.

21. Alis H, Gonenc M, Deniztas C, Kapan S, Turhan AN. Metal endoclips for the closure of the appendiceal stump in laparoscopic appendectomy. Tech Coloproctol 2012;16:139-141.

22. Partecke LI, Kessler W, von Bernstorff W, Diedrich S, Heidecke CD, Patrzyk M. Laparoscopic appendectomy using a single polymeric clip to close the appendiceal stump. Langenbecks Arch Surg 2010;395:1077-1082.

23. Gonenc M, Gemici E, Kalayci MU, Karabulut M, Turhan AN, Alis H. Intracorporeal knotting versus metal endoclip application for the closure of the appendiceal stump during laparoscopic appendectomy in uncomplicated appendicitis. J Laparoendosc Adv Surg Tech A 2012;22:231-235.

24. Khanna S, Khurana S, Vij S. No clip, no ligature laparoscopic appendectomy. Surg Laparosc Endosc Percutan Tech 2004;14:201-203.

25. Kiudelis M, Ignatavicius P, Zviniene K, Grizas S. Analysis of intracorporeal knotting with invaginating suture versus endoloops in appendiceal stump closure. Wideochir Inne Tech Maloinwazyjne 2013;8:69-73.

26. Aziret M, Çetinkünar S, Erdem H, Kahramanca Ş, Bozkurt H, Dülgeroğlu O, Yıldırım AC, İrkörücü O, Gölboyu EB. Comparison of open appendectomy and laparoscopic appendectomy with laparoscopic intracorporeal knotting and glove endobag techniques: A prospective observational study. Turk J Surg 2017;33:258-266.

27. Ay N, Dinç B, Alp V, Kaya Ş, Sevük U. Comparison of outcomes of laparoscopic intracorporeal knotting technique in patients with complicated and noncomplicated acute appendicitis. Ther Clin Risk Manag 2015;11:1213-1216.

28. Quezada F, Quezada N, Mejia R, Brañes A, Padilla O, Jarufe N, Pimentel F. Laparoscopic versus open approach in the management of appendicitis complicated exclusively with peritonitis: A single center experience. Int J Surg 2015;13;80-83.

29. Pedersen AG, Petersen OB, Wara P, Rønning H, Qvist N, Laurberg S. Randomized clinical trial of laparoscopic versus open appendicectomy. $\mathrm{Br}$ J Surg 2001;88:200-205.

30. Ball CG, Kortbeek JB, Kirkpatrick AW, Mitchell P. Laparoscopic appendectomy for complicated appendicitis: an evaluation of postoperative factors. Surg Endosc 2004;18:969-973. 